\title{
PENGARUH KONDISI KEUANGAN PERUSAHAAN, UKURAN PERUSAHAAN, PERTUMBUHAN PERUSAHAAN DAN REPUTASI KAP TERHADAP PENERIMAAN OPINI AUDIT GOING CONCERN PADA PERUSAHAAN PERTAMBANGAN YANG TERDAFTAR DI BURSA EFEK INDONESIA TAHUN 2015-2017
}

\author{
Rivaldi Akbar*1, Ridwan ${ }^{* 2}$ \\ 1,2Program Studi Akuntansi Fakultas Ekonomi dan Bisnis Universitas Syiah Kuala \\ e-mail: rvldkbr@gmail.com ${ }^{* 1}$, ridwan.ibrahim@ unsyiah.ac.id ${ }^{* 2}$
}

\begin{abstract}
This study aims to examine the effect of financial distress, size firms, growth companies, and reputation public accounting firm on acceptance of going concern opinion. The method of this research is a quantitativ approach and SPSS as an analysis tool. Object under study is a mining companies listed on Indonesia Stock Exchange during the periode 2015-2017,as many 33 companies for 3 years with 99 total sample. Testing is done by using logistic regresion analysis by using SPSS version 25.The result showed that the financial distress proxied by the calculation of altman modification model has no significant on the acceptance of going concern audit opinion. Second, the firm size has significant and positive effect on the acceptance of going concern opinion. Third, the growth companies has significant and negative effect on the acceptance of going concern opinion. Finally, the reputation of the public accounting firm proxied at the scale of the public accounting firm has no significant effect on the acceptance of going concern audit opinion
\end{abstract}

Keywords: Ukuran Perusahaan, Opini Audit, Penerimaan Opoini Audit, Reputasi KAP.

\section{Pendahuluan}

Banyak pihak beranggapan bahwa ketika auditor memberikan opini wajar maka hal ini merupakan penjamin agar perusahaan tidak bangkrut dalam waktu yang dekat, Akibatnya kebanyakan auditor banyak dituduh bersalah atas kebangkrutan yang dialami oleh perusahaan. Auditor tidak mempunyai tanggung jawab untuk mengestimasi kebangkrutan, namun investor berharap mendapatkan sinyal peringatan dini (early warning signal) dari auditor mengenai keberlangsungan hidup perusahaan (Chen dan Church, 1996 dalam oktavia, 2010:306).

Fenomena manipulasi semakin banyak terjadi di beberapa perusahaan besar. Pertama kali terjadinya kasus besar mengenai manipulasi telah membuat banyak pihak dan pengguna laporan keuangan resah, terlebih Kantor Akuntan Publik (KAP) yang terlibat pada kasus ini merupakan Arthur Andersen. Pada tahun sebelum terjadinya kebangkrutan, KAP Arthur Andersen yang bertugas untuk mengauditmemberikan opini wajar tanpa pengecualian. Auditor adalah pihak yang paling dianggap bertanggung jawab dalam masalah ini

Di Indonesia sendiri kasus mengenai bangkrutnya suatu perusahaan setelah mendapatkan opini wajar tanpa pengecualian telah banyak terjadi, misalnya kasus yang terjadi pada awal tahun 1990 pada bank Summa,yang mendapatkan laporan audit yang wajar namun mengalami kebangkrutan pada tahun berikutnya. Pemerintah sejak 1 November 1997 melakukan likuidasi terhadap beberapa perusahaan, di antaranya Bank Ratu dan Bank Prasidha Utama yang pada tahun 2000 diberhentikan oleh pemerintah. Kantor akuntan publik yang bertugas membuat laporan audit perusahaan menyatakan perusahaan dalam kondisi baik namun kenyataannya dalam keadaan yang buruk.

Auditor seringkali mengalami kesulitan dalam memprediksi going concern (keberlangsungan hidup) sebuah entitas, dilema antara moral dan etika dialami oleh auditor dalam menyampaikan opini audit going concern (Januarti, 2007, dalam Alfaizatul, 2012:8). Ketentuan AICPA (American Institute of Certified 
Accountants) mengharuskan auditor untuk secara jelas menyatakan kemampuan perusahaan klien dalam mempertahankan keberlangsungan hidupnya. Menurut Levitt (1998) dalam Fanny dan Saputra (2005) sebelum menentukan apakah ikut berinvestasi atau tidak, investor terlebih dahulu melakukan analisis laporan keuangan. Investor mengharapkan auditor handal dalam memberikan informasi yang baik. Fokus seorang auditor adalah penentuan apakah informasi benar-benar mencerminkan peristiwa yang terjadi saat periode akuntansi (Arens, Elder, dan Beasley, 2008 dalam kristiana, 2012:47).

Keberlangsungan hidup perusahaan adalah masalah yang sangat berpengaruh bagi pihak didalam perusahaan yang mempunyai kepentingan terutama investor. Penanaman modal dari investor diharapkan mampu untuk mendanai kegiatan perusahaan dalam jangka waktu yang panjang dan juga investor mengharapkan memperoleh dividen dari modal yang diinvestasikan. Maka dari itu sebelum investor melakukan kegiatan investasi sangat dianjurkan perlu melihat kondisi perusahaan melalui laporan keuangan yang dibuat oleh perusahaan. Semua pihak pasti menginginkan opini audit yang diharapkan, karena harga saham akan berpengaruh terhadap keputusan investor dalam menanamkan modal dan juga kehilangan kepercayaan terhadap manajemen perusahaan. Hilangnya kepercayaan publik akan berdampak pada keberlangsungan hidup perusahaan pada saat mendatang.

Jumlah perusahaan pada Bursa Efek Indonesia (BEI) dari tahun ke tahun dapat menurun akibat adanya wewenang delisting yang dilakukan oleh BEI. Apabila perusahaan mengalami kondisi negatif terhadap keberlangsungan usahanya dan tidak bisa membuktikan rencana pemulihan yang memadai, maka pihak BEI berhak menghapus pencatatan saham pada perusahaan tersebut sesuai dengan peraturan bursa nomor I-I tentang pencatatan kembali (relisting) dan penghapusan (delisting).

Dalam kurun waktu 8 tahun sejak bergabungnya bursa efek Jakarta dan Bursa Efek Surabaya pada tahun 2009 sampai dengan 2016, Bursa Efek Indonesia telah mendelisting 28 perusahaan dan sejak 2012 sampai 2016 sebanyak 15 perusahaan mengalami delisting. Hal ini mengindikasikan bahwa banyak perusahaan yang tidak mampu mempertahankan keberlangsungan usahanya sehingga membuat banyak pihak yang berkepentingan harus berhati-hati dalam mengambil keputusan.

Tabel 1.1

Perusahaaan yang di delisting

\begin{tabular}{|c|c|c|c|}
\hline Tahun & $\begin{array}{c}\text { Jumlah Perusahaan } \\
\text { Terdaftar }\end{array}$ & Pertambahan/Tahun & Delisting \\
\hline 2012 & 463 & - & 4 \\
\hline 2013 & 486 & 23 & 7 \\
\hline 2014 & 509 & 23 & 1 \\
\hline 2015 & 525 & 6 & 3 \\
\hline 2016 & 531 & 68 & 15 \\
\hline & Jumlah 5 tahun & & 0 \\
\hline
\end{tabular}

Fenomena banyaknya delisting ini menggambarkan bahwa masih banyak perusahaan yang tidak mampu mempertahankan keberlangsungan usahanya, sehingga menimbulkan banyak kekhawatiran di kalangan para pemakai laporan keuangan di semua sektor perusahaan, tak terkecuali di sektor pertambangan. Sektor pertambangan adalah salah satu yang menjadi sektor yang paling berpengaruh bagi perkembangan perekonomian negara disebabkan konstribusinya dalam penyediaan sumber daya energi yang dibutuhkan untuk kebutuhan negara, oleh karena itu dalam mengeksplorasi sumber daya alam.

Menurut Junaidi dan Hartono (2010:1) dalam Saputra (2017:684) diperlukan faktor pengukur yang dapat menentukan opini going concern karena going concern adalah masalah kompleks dan terus ada, sehingga investor dapat menjadikannya acuan dalam investasinya. Fenomena opini audit going concern telah menarik perhatian para peneliti dalam melaksanakan pengkajian going concern dengan keterkaitannya bersama variabel lain, dalam penelitian ini peneliti meninjau dari faktor kondisi keuangan perusahaan, ukuran perusahaan, pertumbuhan perusahaan dan reputasi KAP.

Faktor pertama yaitu kondisi keuangan perusahaan. Buruknya kondisi keuangan akan mengakibatkan kesempatan untuk mendapatkan kualifikasi going concern opinion semakin tinggi, Begitupun jika kondisi keuangan baik, peluang memperoleh opini going concern makin kecil. Banyak kasus yang terjadi saat kondisi keuangan buruk tetapi perusahaan berusaha untuk menampilkan laporan keuangan yang baik di hadapan para pengguna 
laporan keuangan tersebut, akibatnya pendapat auditor akan terpengaruh penyajian pada laporan keuangan, padahal laporan keuangan tidak menyajikan hal-hal yang memperlihatkan kondisi keuangan tersebut buruk. Kasus terbaru mengenai manipulasi data dialami oleh bank bukopin yang diduga melakukan manipulasi data kartu kredit, telah terjadi selama 5 tahun dengan pemodifikasian data kartu kredit. Situasi ini juga dianngap serius karena KAP yang bertugas di Bukopin adalah KAP yang berafiliasi dengan Erns \& Young yang merupakan salah satu bigfour.

Faktor kedua adalah ukuran perusahaan. Auditor beranggapan bahwa perusahaan besar akan lebih memiliki kemampuan menyelesaikan kondisi keuangannya dibandingkan perusahaan kecil yang memiliki peluang untuk menerima going concern opinion. Ukuran perusahaan yang besar akan lebih memudahkan perusahaan untuk mendapatkan sumber pendanaan karena perusahaan besar akan lebih mudah memenangkan persaingan. Misalnya ketika dua perusahaan di dalam satu industri bersaing untuk mendapatkan sumber pendanaan maka ukuran perusahaan menjadi penentu para pemberi dana untuk menginvestasikan dananya, dan secara langsung perusahaan yang mendapatkan dana akan lebih mampu untuk melanjutkan usahanya. Namun pada kenyataannya sebesar apapun perusahaan tidak terlepas kemungkinannya dari potensi kebangkrutan.

Faktor ketiga adalah pertumbuhan perusahaan. Pertumbuhan perusahaan menggambarkan kemampuan entitas untuk melanjutkan keberlangsungan usahanya. Ditinjau dari faktor pertumbuhan perusahaan, sektor pertambangan adalah sektor yang sangat rentan terjadinya kebangkrutan, karena data menunjukkan bahwa pertumbuhan perusahaan di sektor ini merupakan pertumbuhan yang paling rendah di antara sektor lainnya. Kemampuan perusahaan untuk melanjutkan usahanya bisa bergantung dari pertumbuhan perusahaan. Menurut Statistik, tingkat pertumbuhan Produk Domestik Bruto (PDB) sektor pertambangan relatif sangat kecil dibanding dengan sektor lainnya dan mempunyai tingkat pertumbuhan yang menurun dari tahun ke tahun. Berikut adalah data statistik tingkat pertumbuhan PDB dari sisi sektoral dari tahun 2013 hingga 2017.
Tabel 1.2

Pertumbuhan PDB Sisi Sektoral

(Persen,Year on year)

\begin{tabular}{|l|c|c|c|c|c|}
\hline lapangan usaha & $\mathbf{2 0 1 3}$ & $\mathbf{2 0 1 4}$ & $\mathbf{2 0 1 5}$ & $\mathbf{2 0 1 6}$ & $\mathbf{2 0 1 7}$ \\
\hline Pertanian, Kehutanan dan Perikanan & 4,20 & 4,24 & 3,75 & 3,36 & 3,81 \\
\hline Pertambangan dan Penggalian & $\mathbf{2 , 5 3}$ & $\mathbf{0 , 4 3}$ & $\mathbf{- 3 , 4 2}$ & $\mathbf{0 , 9 5}$ & $\mathbf{0 , 6 9}$ \\
\hline Industri Pengolahan & 4,37 & 4,64 & 4,33 & 4,26 & 4,27 \\
\hline Pengadaan Listrik & 5,23 & 5,90 & 0,90 & 5,39 & 1,54 \\
\hline $\begin{array}{l}\text { Limbah dan daur ulang, Pengelolaan } \\
\text { Sampah, Pengadaan air }\end{array}$ & 3,32 & 5,24 & 7,07 & 3,60 & 4,61 \\
\hline Konstruksi & 6,11 & 6,97 & 6,36 & 5,22 & 6,79 \\
\hline Perdagangan Besar dan Eceran, & 4,81 & 5,18 & 2,54 & 4,03 & 4,44 \\
\hline Transportasi dan Pergudangan & 6,80 & 5,77 & 4,31 & 5,17 & 5,55 \\
\hline Jasa Keuangan & 8,76 & 4,68 & 8,58 & 8,90 & 5,48 \\
\hline Real Estate & 6,54 & 5,00 & 4,11 & 4,69 & 3,68 \\
\hline
\end{tabular}

Sumber : Laporan Perekonomian Indonesia 2017

Berdasarkan tabel di atas bisa kita amati bahwa sektor pertambangan adalah sektor yang paling sedikit pertumbuhan Produk Domestik Brutonya, penurunan tersebut disebabkan oleh faktor ekonomi makro dan masalah ekonomi global. Hubungan Produk Domestik Bruto dengan going concern adalah apabila Produk Domestik Bruto terus menurun seharusnya auditor memberikan opini audit going concern tetapi faktanya masih banyak perusahaan di sektor pertambangan yang belum mendapatkan opini audit going concern. sehingga peneliti ingin mempelajari apakah penerimaan opini audit going concern dipengaruhi karena pertumbuhan perusahaaan.

Faktor keempat yang ingin diteliti adalah reputasi KAP. Kantor akuntan publik merupakan lembaga yang bertanggung jawab atas kinerja audit yang diberikan oleh auditor eksternal sebuah perusahaan. Kualitas kantor akuntan publik bisa juga diproksikan dengan kualitas auditor, karena auditor yang bertugas menilai laporan keuangan pasti dibawah naungan kantor akuntan publik tempat dia bekerja. Besarnya KAP dapat dikategorikan menjadi bigfour dan nonbigfour. Kantor akuntan publik yang terafiliasi big four memiliki reputasi yang tinggi daripada bukan dari bigfour, reputasi yang tinggi memudahkan kantor akuntan publik untuk memilih klien, sehingga mereka cenderung memilih klien yang tidak bermasalah dengan keberlangsungan perusahaan mereka.

KAP yang mempunyai reputasi baik akan menerbitkan going concern opinion apabila terdapat permasalahan keberlangsungan usaha di usaha tersebut. Kualitas audit yang tinggi dapat diberikan oleh KAP yang terafiliasi bigfour karena mereka dinilai lebih independen dalam memberikan opini 
audit. Kenyataan yang terjadi adalah seberapa baik pun reputasi yang dimiliki oleh kantor akuntan publik tidak menjamin bahwa KAP tersebut dapat memprediksi keberlangsungan hidup perusahaan, terbukti dengan kasus yang terjadi di Enron yang melibatkan KAP Arthur Andersen yang akhirnya bangkrut setelah diberikan opini wajar tanpa pengecualian.

\section{Kerangka Teoritis Dan Pengembangan Hipotesis \\ Kajian Pustaka \\ Opini Audit}

Auditor menggunakan laporan audit sebagai media untuk berhubungan dengan lingkungannya. Standar audit membagi opini audit menjadi 2 macam, yaitu:

1) Opini tanpa modifikasian (SA 700)

a) Opini wajar tanpa pengecualian

Opini ini dikeluarkan jika berdassarkan hasil audit laporan keuangan telah disajikan secara wajar dalam semua hal yang material telah sesuai dengan prinsip akuntansi yang berlaku umum

2) Opini dengan modifikasi (SA 705)

a) Pendapat wajar dengan pengecualian dapat diberikan ketika auditor meyakini atas dasar auditnya bahwa laporan keuangan ditemukan kesalahan dalam laporan keuangan yang mempunyai nilai material tetapi tidak pervasif. Auditor harus mengungkapkan alasan-alasan yang dapat menegaskan dalam satu ataupun beberapa paragraf secara tersendiri dan dituliskan tepat di atas paragraf opini apabila auditor memberikan pendapat wajar dengan pengecualian. Auditor harus mengacu ke paragraf penjelasan.

b) Pendapat tidak wajar

Dimana menurut pandangan auditor, laporan keuangan yang dilaporkan secara tidak adil atau wajar dan terdapat kesalahan yang material serta pervasif

c) Pernyataan tidak memberikan pendapat Auditor tidak mendapatkan perolehan bukti yang cukup sebagai bahan pertimbangan dalam menyampaikan opini audit

\section{Penerimaan Opini Audit Going Concern}

Going concern diartikan sebagai kemampuan entitas bisnis untuk mempertahankan keberlangsungan hidupnya secara terus menerus (Stevanus, 2013). going concern opinion yang diterima perusahaan oleh auditor dapat disebabkan dari faktor luar maupun faktor di dalam perusahaan itu sendiri. Auditor berkewajiban untuk tidak hanya memeriksa sebatas pada hanya laporan keuangan tetapi melihat kejadian yang berpeluang bisa mengakhiri keberlangsungan usaha. Walaupun pengamatan kelanjutan perusahaanbukan tujuan dapam proses audit, namun auditor mempunyai tanggung jawab dalam menilai kemampuan perusahaan agar bisa tetap beroperasi.

Satu bentuk khusus ketidakpastian yang harus dipertimbangkan auditor adalah kelanjutan entitas bisnis. Suatu bisnis dalam kondisi dapat melanjutkan usahanya jika dapat beroperasi di masa mendatang dan memenuhi kewajibannya. (Junaidi dan Nurdiono, 2016:14)

Untuk memastikan melakukan investasi atau tidak, investor akan menjadikan laporan audit sebagai bahan pertimbangan, karena pendapat yang diberikan oleh auditor dapat memberikan jaminan bahwa pelaporan keuangan telah dilakukan sesuai dengan prinsip yang dapat diterima secara umum. Jika auditor bisa merumuskan ataupun tidak merumuskan opini mengenai wajara atau tidaknya laporan keuangan cocok dengan prinsip yang dapat diterima secara umum maka auditor dapat tidak menyampaikan suatu opini.

Adapun petunjuk mengenai dampak kualifikasi perusahaan untuk melanjutkan keberlangsungan usahanya diatur dalam SA 341 (IAPI, 2011), yakni

1) Tanggung jawab auditor

Kelanjutan usaha menjadi tanggung jawab auditor untuk mengevaluasi agar perusahaan terhindar dari kebangkrutan. Jika auditor merasakan adanya hal hal yang dapat mengganggu keberlangsungan usaha, maka auditor harus

a) Mencari informasi yang akan dilakukan manajemen mengenai rencana yang akan dilakukan supaya dampak kondisi dapat di minimalisir

b) Menilai rencana yang dibuat apakah dapat dilaksanakan secara efektif ataukah tidak 
Kenyataan bahwa perusahaan yang berkemungkinan mengalami kebangkrutan setelah menerima laporan auditor yang sebelumnya tidak terdapat indikasi, ini bukan berarti bahwa kinerja audit rendah. Tidak dijelaskannya indikasi besar seharusnya dianggap sebagai jaminan perusahaan untuk melanjutkan operasinya.

2) Prosedur Audit

Dalam prosedur audit, Auditor tidak diharuskan membuat tujuan tunggal supaya melihat peristiwa dan situasi yang apabila dinilai dapat membuktikan adanya sangsi tinggi tentang kemampuan perusahaan dalam melindungi keberlansungan hidupnya.

3) Pertimbangan atas Kondisi dan Peristiwa

Auditor bisa mengidentifikasi informasi tentang kejadian dan situasi tertentu yang berindikasi besar dapat mengganggu mengenai keberlangsungan hidup perusahaan pada jangka waktu tertentu. penjelasan yang dapat dipakai sebagai indikasi yaitu:

a) Trend negatif. Contohnya kekurangan modal kerja, kerugian operasi dan rasio keuangan buruk.

b) Indikasi lain yang menyulitkan. Misalnya tidak mampu membayar (default) pinjaman, keterlambatan pembayaran dividen, restrukturisasi utang, pengajuan permintaan kredit biasa yang ditolak oleh pemasok, kebutuhan untuk mencari sumber pembiayaan baru maupun aset yang ingin dijual.

c) Hal-hal yang berhubungan dengan masalah internal. Contohnya pemogokan buruh atau kesulitan lain yang berhubungan dengan industrial, ketergantungan yang tinggi atas proyek-proyek tertentu, serta komitmen ekonomi jangka panjang.

d) Hal-hal yang berkaitan dengan masalah eksternal. Misalnya kehilangan franchise, atau kehilangan akibat bencana banjir

4) Tinjauan rencana manajemen

a) Apabila manajemen tidak mempunyai perencanaan dalam menurunkan efek negatif dari situasi dan kejadian terhadap kapabilitas perusahaan dalam melindungi keberlangsungan hidupnya, Auditor bisa meninjau untuk memberikan opini tidak memberikan pendapat b) Apabila manajemen mempunyai perencanaan dalam menurunkan efek yang negatif maka sebaiknya keberhasilan rencana tersebut dipertimbangkan oleh auditor, yaitu Jika program manajemen telah dipertimbangkan dinilai bahwa terdapat kekhawatiran besar perusahaan untuk melanjutkan keberlangsungan hidupnya, maka auditor harus menilai segala dampak yang ditimbulkan serta kecukupan pengungkapannya. Peristiwa yang bisa diungkapkan, yaitu:

(1) Peristiwa yang menyebabkan indikasi besar dalam perusahaan dalam melanjutkan keberlangsungan usahanya

(2) Dampak yang mungkin akan timbul dari peristiwa

(3) Penilaian manajemen mengenai dampak atas kejadian yang dapat menurunkan dampak buruknya

(4) Peluang berakhirnya usaha suatu saat

(5) Rencana dari pihak manajemen

Kerelaan pihak kreditur dan pemegang saham menjalankan restrukturisasi utang jatuh tempo dan pendanaan, wajib dipertimbangkan dalam membuat penilaian asumsi going concern jika masih berlaku. Perusahaan yang ditaksir menurut keuangan bagus, dapat saja tahun selanjutnya dinyatakan bangkrut karena belum bisa memenuhi kewajiban. Faktor keuangan dan non-keuangan bisa mengindikasikan risiko kegagalan perusahaan tersebut.

Menurut Purba (2009:78) Pencantuman kondisi perusahan dalam catatan atas laporan keuangan dianggap sebagian besar akuntan publik menjadi suatu “warning” untuk pengguna laporan keuangan kepada kondisi keuangan perusahaan. Investor berharap kepada auditor agar dapat menyampaikan sinyal peringatan dini "early warning" agar dapat mengambil keputusan.

\section{Kondisi Keuangan Perusahaan}

Menurut Jayanti (2015) Kondisi keuangan merupakan representasi dari kinerja perusahaaan. Keadaan keuangan auditee dapat memberikan keterkaitan penting terhadap keputusan yang diambil. Kondisi keuangan bisa menggambarkan keberlangsungan hidup suatu entitas pada saat mendatang. Para pemakai laporan keuangan selain 
bisa melihat kondisi keuangan suatu perusahaan juga dapat memprediksi apakah perusahaan tersebut dapat mempertahankan usahanya pada saat mendatang.

Analisis kondisi keuangan perusahaan yang dipakai dalam meramalkan kebangkrutan di saat nanti menggunakan suatu model yang disebut model prediksi kebangkrutan. Peringatan dini bagi perusahaan supaya tidak di delisting dan berakhir pada kebangkrutan didapat melalui model prediksi kebangkrutan ini. Untuk mengestimasi kebangkrutan terdapat lima model yang digunakan, yaitu

1) Model Zmijewski

Prediksi memakai pengukuran analisis rasio leverage, profitability, dan liquidity digunakan dalam model Zmijewski. 40 entitas yang sudah dilikuidasi dan 800 entitas yang sedang bertahan pada masa itu digunakan sebagai probit analisis model ini.

2) Model Springate

Metode yang dipakai Altman (1968) dikembangkan oleh Gordon Springate pada 1978. Springate memakai analisis multidiskriminan dan menggunakan empat rasio dari 19 rasio keuangan dengan memakai 40 entitas sebagai contohnya. Keakuratan memprediksi kebangkrutan menggunakan model ini dinilai sebanyak 92,5 persen.

3) Model Altman (Z-score)

Menurut Altman (1968) pengukuran dengan menggunakan lima jenis rasio keuangan yaitu earning before interest and taxes to total assets, working capital to total assets, market value of equity to book value of total debts, retained earning to total assets, dan sales to total assets memakai metode multiple discriminant analysis merupakan rasio yang paling berpengaruh daripada rasio keuangan yang lain.

4) Model Altman revisi ( $Z$ '-score)

Pada tahun 1983 perumusan yang dibuat oleh Edward I. Altman di tahun 1968 mengalami perevisian. Letak perevisian model ini ada pada market value of equity yang berganti book value of equity di variabel X4. Tujuannya adalah mennyesuaikan model agar dapat digunakan tidak hanya perusahaan yang go public tetapi juga yang tidak go public
5) Model Altman Modifikasi (Z"-score)

Modifikasi model Altman sebelumnya terjadi pada tahun 1995. Modifikasi ini terjadi di variabel perputaran aset (X5) dimana Altman mengeliminasinya agar meminimalisir efek industri. Banyak perusahaan akan dapat diterapkan dengan menggunakan model ini, baik yang manufaktur maupun non-manufaktur.

\section{Ukuran Perusahaan}

Ukuran perusahaan adalah suatu skala dimana dapat dikelompokkan besar atau kecilnya perusahaan menurut berbagai cara, antara lain : log total aktiva, $\log$ total penjualan, kapitalisasi pasar. Logaritma natural adalah logaritma dengan menggunakan basis bilangan e. Bilangan e ini seperti halnya bilangan $\pi$, merupakan bilangan nyata dengan desimal tak terhingga" (Sudirham, 2011).

Perusahaan kecil cenderung akan mendapatkan going concern audit opinion oleh auditor. Hal ini disebabkan oleh auditor yang menilai bahwa perusahaan besar akan makin sanggup untuk mengatasi kesulitan keuangan yang dialaminya dibanding perusahaan menengah atau kecil. Investor dapat memakai skala operasi untuk pengelompokan perusahaan sebagai salah satu variabel untuk mengambil keputusan (Dhartia, 2012). Dalam menentukan ukuran perusahaan dapat ditentukan tingkatnya, seperti jumlah karyawan baik karyawan tetap maupun honorer yang bekerja di perusahaan, tingkat penjualan yaitu total dari penjualan perusahaan di periode tertentu, total hutang perusahaan periode tertentu, dan jumlah aset perusahaan pada periode tertentu.

Dibanding perusahaan kecil, perusahaan besar mempunyai manajemen yang kian efisien untuk mengoperasikan usahanya dan berkemampuan mewujudkan kualitas laporan keuangan yang makin baik (Junaidi dan Hartono,2010). Perusahaan besar memiliki kecenderungan untuk dapat lebih dipercaya dibandingkan dengan perusahaan kecil.

\section{Pertumbuhan perusahaan}

Perusahaan dapat mempertahankan keberlangsungan hidupnya dan mempertahankan posisi ekonomi dengan kegiatan operasional perusahaan dengan sewajarnya ditunjukkan oleh perusahaan yang mengalami pertumbuhan (Siregar 
dan Rahman, 2012). Peningkatan volume penjualan yang lebih baik dari tahun sebelumnya dapat digolongkan sebagai entitas dengan pertumbuhan yang baik (Dewayanto 2011). Keadaan ini berarti bahwa kapabilitas entitas untuk mempertahankan kondisi perekonomiannya dalam memberi kesempatan perusahaan untuk mempertahankan keberlangsungan hidupnya serta meningkatkan volume pertumbuhannya.

Dana dalam menjalankan aktivitas operasi dibutuhkan oleh perusahaan yang sedang bertumbuh. Pertumbuhan perusahaan bisa kita tinjau dengan pertumbuhan penjualan, laba, dan aktiva. Pertumbuhan akibat proses aktivitas operasi pada periode yang berlanjut dengan menigkatnya penjualan. Pihak eksternal dan internal sangat mengharapkan pertumbuhan perusahaan, sebab pertumbuhan yang baik mengindikasikan bahwa perusahaan telah berkembang ke arah yang lebih baik. Dari pandangan investor, pertumbuhan perusahaan mencerminkan profitabilitas perusahaan yang tinggi, karena investor mengharapkan laba atas kegiatan investasi yang dilakukannya. Menurut Brigham dan Houston (2011:189) perusahaan yang tumbuh cepat perlu bergantung pada modal eksternal. Pertumbuhan perusahaan menunjukkan kemampuannya mempertahankan bisnis.

Peningkatan aset perusahaan adalah kinerja perusahaan dalam memajukan pertumbuhannya. Perusahaan baik bisa di lihat dari penjualan dan produksi yang terus meningkat. Pertumbuhan perusahaan dapat diproksikan dari banyaknya total perubahan aset untuk perbandingan penurunan maupun kenaikan total aset yang dimiliki oleh perusahaan

\section{Reputasi KAP}

Reputasi KAP dilihat dari kepercayaan masyarakat atas kinerja yang diperoleh oleh kantor akuntan publik itu sendiri.Reputasi kantor akuntan publik sering diproksikan dengan reputasi auditor. KAP besar lebih memiliki kualitas audit bertambah tinggi, sehingga mutu audit yang dikeluarkan juga lebih tinggi. KAP yang tergolong besar adalah KAP yang tergolong dalam big four auditors. KAP yang berskala besar biasanya menciptakan kualitas audit makin baik dibanding KAP yang mempunyai ukuran kecil. KAP sebagai bagian dari big four dapat mengaudit makin efektif dan mempunyai fleksibelitas lebih tinggi pada agenda audit sehingga bisa dituntaskan tepat waktu (Türel, 2010).

Lazimnya para pemakai laporan keuangan akan dengan cepat mengetahui bahwa suatu KAP yang diseleksi memang betul-betul meiliki keahlian yang memadai dan integritas yang tinggi untuk memberi pertanggungan kepada para pemakai laporan keuangan , baik para eksekutif lembaga keuangan maupun kepada calon investor untuk menjadi pengarahan bagi mereka sebelum mengeluarkan hasil keuangan. Maka dari itu para pemakai laporan keuangan setidaknya mempertimbangkan reputasi KAP dari perusahaan yang memakai jasanya.

KAP yang mempunyai kepakaran khusus dalam aspek industri tertentu, akan lebih berupaya memberikan jasa yang lebih baik dibanding KAP lain yang belum pernah menanggulangi aspek tertentu. Faktor pengalaman dan bidang khusus akan menambah keefisiensinan bantuan jasa yang diberikan. Hal ini tentu menambah jaminan bahwa perusahaan akan memperoleh status jasa yang lebih baik terutama pada peningkatan saran mengenai pemulihan sistem pengendalian intern.

Menurut Junaidi dan Hartono (2010:7) KAP big four cenderung mengeluarkan going concern opinion jika auditee ada persoalan going concern di perusahaannya. Reputasi KAP dilihat sebagai salah satu penyebab meningkatnya kualitas suatu laporan keuangan bagi perusahaan. Setiap KAP yang mempunyai reputasi yang baik akan selalu berupaya melindungi reputasinya di kalangan pengguna laporan keuangan.

Kantor Akuntan Publik yang masuk ke dalam 4 besar di Indonesia diasosiasikan dengan 4 jaringan CPA internasional. Baik dari segi jumlah tenaga kerja juga dari segi pendapatan, yaitu Ernst\&Young Global, pricewaterhouseCoopers, KPMG international, dan deloitte touche tohmatsu. Kantor akuntan publik memiliki kantor hampir di semua negara dan sering disebut bigfour

\section{Kerangka Pemikiran}

Melihat pada penelitian sebelumnya Kusumayanti dan Widhiyani (2016) dalam penelitiannya yang berjudul "pengaruh opinion shopping, disclousure dan reputasi KAP pada opini audit going concern" mengambil sampel pada bursa 
efek Indonesia di sektor manufaktur periode 20112015. Hasil penelitiannya menyebutkan variabel Reputasi KAP berpengaruh pada going concern opinion. Harapan peneliti adalah objektivitas dan independensi auditor tetaplah terjaga meskipun auditor tidak tergabung dengan KAP bigfour. Sebaiknya pemberian going concern opinion langsung diberikan apabila ada kekhawatiran mengenai keberlangsungan usahanya

Saputra dan Praptoyo (2017) dalam penelitiannya "analisis faktor yang mempengaruhi opini terkait going concern" meneliti tentang hubungan antara opini audit tahun sebelumnya, kondisi keuangan perusahaan, kualitas audit, bukti audit, pertumbuhan perusahaan dan interaksi antar variabel tersebut di perusahaan tercatat pada BEI. Hasil dari penelitian ini, dapat disimpulkan bahwa going concern opinion dipengaruhi negatif oleh kondisi keuangan perusahaan, Namun, terkait going concern tidak signifikan dipengaruhi oleh ukuran perusahaan dan pertumbuhan perusahaan.

Syarifah (2016) dalam penelitiannya yang berjudul "Pengaruh Faktor Keuangan dan Non Keuangan Terhadap Pemberian Opini Audit going concern". Penelitiannya mengambil sampel pada BEI sebanyak 108 sampel selama rentang waktu 2012 sampai dengan 2015. Hasil dari penelitian sesudah dilakukan analisis data adalah going concern opinion secara signifikan dipengaruhi oleh variable kondisi keuangan.

Haron et al., (2009) dalam "Factors Influencing Auditors' Going Concern Opinion". Penelitian ini menilai penilaian auditor melalui tiga faktor, yaitu indikator pengungkapan, bukti, dan indikator keuangan. Hasilnya ditemukan terdapat konsensus kuat di antara tiga variabel independen dan efek interaksi dari ketiga variabel ini adalah signifikan yang berarti bahwa auditor mempertimbangkan ketiga faktor secara bersamaan.

Gallizo dan Saladrigues (2015) dalam penelitian mereka yang berjudul "An analysis of determinants of going concern audit opinion: evidence from Spain stock exchange". Pada penelitian ini mereka mengambil sampel pada tahun 2012, dengan total 48 perusahaan, dan hasilnya membuktikan, semakin menguntungkan perusahaan, maka peluang dalam memperoleh going concern audit opinion akan semakin rendah, dan semakin besar skala perusahaan auditnya maka semakin rendah peluang untuk mendapatkan going concern opinion.

Lestari dan Widhiyani (2014) dalam penelitiannya yang berjudul "pengaruh faktor Keuangan dan Karakteristik Auditor Pada Kualifikasi Opini dan Keberlangsungan usaha". Obyek penelitiannya merupakan semua perusahaan manufaktur di BEI. Dalam penelitian memakai model non probabilitas melalui teknik purposive sampling. Perolehan dari penelitiannya adalah pertumbuhan perusahaan dan kondisi keuangan perusahaan tidak mempengaruhi kriteria going concern opinion, sedangkan kualifikasi going concern secara positif dipengaruhi oleh reputasi kantor akuntan publik.

\section{Hipotesis}

Hipotesis adalah penarikan kesimpulan temporer yang ditarik sebelum dilakukannya penelitian untuk memperoleh tanggapan kenyataanya. Menurut Sekaran dan Bougie (2013:83), "hipotesis adalah hubungan yang diperkirakan secara logis di antara dua atau lebih variabel yang diungkapkan dalam bentuk pernyataan yang dapat diuji". Hipotesis pada penelitian ini adalah:

H1: kondisi keuangan perusahaan, ukuran perusahaan, pertumbuhan perusahaan, dan reputasi KAP secara bersama-sama memengaruhi penerimaan going concern audit opinion pada perusahaan pertambangan.

H2: Kondisi keuangan perusahaan memengaruhi penerimaan going concern audit opinion pada perusahaan pertambangan

H3: Ukuran perusahaan memengaruhi penerimaan going concern audit opinion pada perusahaan pertambangan.

H4: Pertumbuhan perusahaan memengaruhi penerimaan opini audit going concern pada perusahaan.

H5: Reputasi KAP memengaruhi penerimaan going concern audit opinion pada perusahaan pertambangan.

\section{Metode Penelitian \\ Desain Penelitian}

Untuk menjawab pertanyaan penelitian dibuat suatu rencana kerja yang sistematis dalam hal hubungan antar variabel secara komprehensif yang disebut dengan desain penelitian. Enam aspek dasar 
yang terkandung di dalam desain penelitian, yaitu jenis investigasi, unit analisis, konteks studi, tujuan stu, horizon waktu studi, dan tingkat intervensi peneliti (Sekaran dan Bougie, 2013:95).

Rancangan penelitian ini mengacu pada rancangan Sekaran dan Bougie (2013:95) dengan berpatokan pada aspek yang harus terwujud, Berikut ini adalah aspek yang harus terpenuhi

1) Sifat Studi

Sifat studi yang diterapkan pada penelitian ini adalah pengujian hipotesis. Penelitian ini bermaksud mendeskripsikan sifat dari kaitan variabel, maupun memastikan variasi antar kategori ataupun kebebasan dua atau lebih variabel.

2) Jenis Penelitian

Studi kausalitas digunakan dalam jenis penelitain ini, di mana peneliti hendak menjelaskan dampak antar variabel yang diteliti. Masalah yang ingin diteliti pada penelitian ini merupakan untuk mengetahui going concern audit opinion sebagai variabel dependen yang dipengaruhi oleh berbagai faktor yang merupakan variabel independen.peneliti hendak menjelaskan dampak antar variabel yang diteliti. Masalah yang ingin diteliti pada penelitian ini merupakan untuk mengetahui going concern audit opinion sebagai variabel dependen yang dipengaruhi oleh berbagai faktor yang merupakan variabel independen.

3) Tingkat Intervensi Peneliti terhadap Studi

Intervensi minimal digunakan pada penelitian ini. Dalam hal ini peneliti melihat pengaruh antar variabel saja, dimana data yang didapat dikumpulkan dari laporan keuangan tahunan teraudit.

4) Situasi Studi

Situasi tidak diatur merupakan situasi studi dalam penelitian. Peneliti memandang data-data dihimpun dari laporan keuangan tahunan teraudit saja.

5) Unit Analisis

Unit analisis melihat atas tahap satuan data yang dihimpun semasa fase analisis data selanjutnya (Sekaran dan Bougie, 2013:104). Organisasi merupakan unit analisis dalam penelitian. Unit analisis diteliti merupakan perusahaan pertambangan yang terdaftar di BEI tahun 20152017.

6) Horizon Waktu

Penelitian ini menggunakan horizon waktu times series dan cross-sectional, dimana data yang dikumpulkan dalam beberapa tahun dan dikumpulkan pada banyak objek dalam rangka menjawab pertanyaan penelitian (Sekaran dan Bougie, 2013:177). Data dikumpulkan dari laporan keuangan tahunan teraudit dari tahun 2015 sampai tahun 2017.

\section{Populasi dan Sampel Penelitian}

Populasi pada penelitian ini merupakan perusahaan pertambangan yang terdaftar di BEI dan pada tahun 2015-2017. Metode purposive sampling digunakan untuk pemungutan sampel. Teknik purposive sampling adalah pemilihan sample 2013:131). Unit observasi di dalam penelitian ini adalah perusahaan pertambangan, unit analisisnya adalah perusahaan pertambangan yang mempunyai kriteria tertentu.

Adapun kriteria yang harus dipenuhi dalam penentuan sampel yang dipakai, yaitu:

1) Perusahaan pertambangan yang tecatat pada Bursa Efek Indonesia semasa tahun 2015-2017.

2) Perusahaan pertambangan yang menerbitkan laporan keuangan auditan selama periode penelitian 2015-2017

3) Perusahaan pertambangan yang tidak mengalami delisting dari BEI selama periode penelitian 2015-2017

4) Perusahaan pertambangan yang menyajikan informasi mengenai nama akuntan publik serta opini auditor yang terdapat laporan keuangan auditan.

Berdasarkan kriteria di atas, total sampel yang digunakan dapat dilihat pada Tabel 3.1.

Tabel 3.1

Sampel Penelitian

\begin{tabular}{|c|l|c|}
\hline No & \multicolumn{1}{|c|}{ Kriteria Sampel } & Jumlah Perusahaan \\
\hline 1 & $\begin{array}{l}\text { Perusahaan pertambangan yang terdaftar di } \\
\text { BEI selama periode 2015-2017 }\end{array}$ & 44 \\
\hline 2 & $\begin{array}{l}\text { Perusahaan pertambangan yang tidak } \\
\text { menerbitkan laporan keuangan auditan } \\
\text { selama periode 2015-2017 }\end{array}$ & \\
\hline 3 & $\begin{array}{l}\text { Perusahaan pertambangan yang mengalami } \\
\text { delisting dari BEI selama periode penelitian }\end{array}$ & (5) \\
\hline 4 & $\begin{array}{l}\text { Perusahaan pertambangan yang tidak } \\
\text { menyajikan informasi mengenai nama } \\
\text { akuntan publik serta opini auditor yang }\end{array}$ & \\
\hline
\end{tabular}

Sumber: data diolah (2018) 


\section{Sumber dan Teknik Pengumpulan Data Sumber Data}

Data sekunder adalah data digunakan pada penelitian. Data sekunder adalah data yang menyesuaikan informasi yang dihimpun oleh seseorang atau suatu lembaga, dan bukan peneliti yang melakukan studi mutakhir (Sekaran dan Bougie, 2013:51). Data dalampenelitian merupakan data laporan keuangan teraudit perusahaan pertambangan yang dipublikasikan BEI dari tahun 2015 sampai tahun 2017 melalui websitenya, yaitu www.idx.co.id.

\section{Teknik Pengumpulan Data}

Berikut ini merupakan tekhnik penghimpunan data yang dipakai:

1) Studi kepustakaan

Studi kepustakaan didapatkan dengan mengkaji daftar bacaaan berkaitan dengan hal yang ingin diteliti dalam penelitian ini. Data yang diperoleh dari studi kepustakaan menjadi data pelengkap saja.

2) Metode dokumentasi

Metode dokumentasi dipakai melalui mengamati dokumen yang sesuai, bisa dari laporan keuangan perusahaan ataupun dari eksplorasi internet demi mendapatkan data-data yang menunjang penelitian.

\section{Teknik Pengolahan Data}

Teknik pengolahan data yang dipakai di dalam penelitian ini memakai statistik deskriptif, karena data bersifat kuantitatif. Statistik deskriptif digunakan supaya dapat mendeskripsikan variabel penelitian melalui pengukuran. Data yang telah dikumpulkan kemudian akan disajikan dalam bentuk tabel untuk keperluan analisis. Pengolahan statistik merupakan cara untuk mengolah data kuantitatif agar data mempunyai arti.

\section{Metode Analisis dan Rancangan Pengujian Hipotesis}

Metode Analisis

\section{Analisis Statistik Deskriptif}

Menurut Ghozali (2013:19), statistik deskriptif yaitu teknik yang menggambarkan ataupun mendeskripsikan suatu data yang diteliti. Dalam menggunakan statistic deskriptif, suatu informasi dapat dilihat dari standar deviasi, mean atau nilai rata- rata, maksimum, minimum, varian, sum, range kurtosis dan skeweness. Statistik deskriptif dipakai untuk mengenali ciri-ciri karakteristik suatu kelompok informasi agar mudah dimengerti.

\section{Model Analisis Regresi Logistik}

Metode analisis data yang dipakai dalam penelitian merupakan metode regresi logistik. Menurut Ghozali (20012:9) Metode regresi logistik sesuai dipakai bagi penelitian yang variabel terikatnya bersifat kategori. Dalam penelitian ini digunakan regresi logistik karena variabel dependen dichotomous dan variabel independen yang bersifat metrik dan nonmetrik. Model regresi logistik yang dipakai

$$
\mathrm{LN} \frac{G C}{1-G C}=\mathrm{a}+\mathrm{b}_{1} \mathrm{x}_{1}+\mathrm{b}_{2} \mathrm{x}_{2}+\mathrm{b}_{3} \mathrm{x}_{3}+\mathrm{b}_{4} \mathrm{x}_{4}+\mathrm{e}
$$

Keterangan:

a

$\mathrm{b}_{1}-\mathrm{b}_{4}$

$\mathrm{x}_{1} \quad=$ Kondisi Keuangan

$\mathrm{x}_{2} \quad=$ Pertumbuhan Perusahaan

$\mathrm{x}_{3} \quad=$ Ukuran Perusahaan

$\mathrm{x}_{4} \quad=$ Reputasi KAP

e $\quad=$ Kesalahan Residual

\section{Menilai Model Fit}

Uji menilai keseluruhan model (overall fit test) adalah serangkai prosedur yang dilakukan untuk menilai keseluruhan model regresi. Dengan adanya penambahan variabel independen, data akan diuji apakah model tersebut layak atau tidak untuk digunakan. Statistic yang dipakai berlandaskan pada fungi likehood. Likehood L dari model merupakan kemungkinan bahwa model yang dihipotesiskan menjelaskan data input untuk menguji hipotesis nol dan alternatif (Ghozali, 2011:78).

\section{Uji kelayakan model regresi}

Kelayakan model regresi dinilai dengan memakai hosmer and lemesghow Goodness of Fit Test. Model ini untuk membuat pengujian hipotesis nol bahwa data empiris cocok dengan model yaitu tidak ada perbedaan antara model dengan data sehingga model bisa dikatakan fit. Menurut Ghozali (2009), adapun hasilnya apabila:

1) Apabila nilai statistik homer and lemeshow's Goodness of Fit Test $\leq$ 0,05 maka hipotesis nol ditolak. Keadaan ini mengindikasikan terdapat 
perbedaan antara nilai observasi dengan modelnya sehingga Goodness of Fit model tidak bagus karena model belum dapat memperkirakan nilai observasinya

2) Apabila nilai statistik homer and lemeshow's Goodness of Fit Test > 0,05, maka hipotesis nol diterima dan bermakna model dapat diterima sebab sesuai dengan data observasinya

\section{Koefisien Determinasi}

Koefisien determinasi $\left(\mathrm{R}^{2}\right)$ dapat memberikan informasi mengenai kelayakan dari suatu model regresi. Nilai $\mathrm{R}^{2}$ merupakan ukuran statistik yang menjelaskan seberapa bagus garis regresi menghampiri titik data riil. $\mathrm{R}^{2}$ merupakan persentase varians pada variabel dependen yang digambarkan oleh variasi dalam variabel independen. Apabila nilai $\mathrm{R}^{2}$ adalah 1, maka model regresi memberikan seluruh informasi secara sempurna dalam memperkirakan variasi variabel dependen. Di lain sisi, jika nilai $R^{2}$ adalah 0 , maka tidak ada variasi yang cenderung dapat diterima oleh variabel independen (Sekaran \& Bougie, 2016:313).

\section{Matriks Klasifikasi}

Matriks klasifikasi memperlihatkan kekuatan prediksi dari model regresi untuk memperkirakan kemungkinan going concern opinion yang dilakukan oleh auditor. Tabel klasifikasi $2 \times 2$ menghitung nilai ramalan yang benar (correct) dan salah (incorrect). Pada kolom merupakan dua nilai estimasi dari variabel terikat, sedangkan pada baris mengungkapkan nilai observasi sebenarnya dari variabel terikat. Pada model yang ideal, maka semua kasus akan berada pada tingkat ketetapan estimasi $100 \%$. Apabila model regresi logistik mempunyai homoskedasitisitas, maka bagian yang benar akan sama dalam kedua baris.

\section{Rancangan Pengujian Hipotesis \\ Uji statistik simultan}

Omnibus Test of Model Coefficient dipakai untuk memahami pengaruh secara simultan dari variabel-variabel independen terhadap variabel dependen pada suatu analisis regresi. Jika nilai probabilitas > tingkat signifikansi $(\alpha)$ atau nilai probabilitas >0,05, maka hipotesis diterima. Sebaliknya, jika nilai probabilitas > tingkat signifikansi $(\alpha)$ atau nilai sig $\mathrm{F}<0,05$, maka hipotesis ditolak.

Langkah-langkah yang dipakai guna memperhitungkan variabel bebas secara simultan terhadap variabel terikat, yaitu:

1. Menentukan Hipotesis Nol $\left(\mathrm{H}_{\mathrm{o}}\right)$ dan Hipotesis Alternatif $\mathrm{H}_{\mathrm{A}}$ sebagai berikut:

a) $\mathrm{H}_{\mathrm{o}}: \mathrm{b}_{1}(\mathrm{I}=1,2,3,4)=0$ : kondisi keuangan perusahaan, ukuran perusahaan, pertumbuhan perusahaan dan Reputasi KAP secara simultan tidak mempengaruhi penerimaan opini audit going concern.

b) $\mathrm{H}_{\mathrm{A}}: \mathrm{b}_{\mathrm{I}}(\mathrm{I}=1,2,3,4) \neq 0$ : kondisi keuangan perusahaan, ukuran perusahaan, pertumbuhan perusahaan dan Reputasi KAP secara simultan mempengaruhi penerimaan opini audit going concern.

2. Menetapkan kriteria penerimaan dan penolakan hipotesis yaitu sebagai berikut:

a) Jika $b_{I}(I=1,2,3,4)=0: \mathrm{H}_{\mathrm{o}}$ diterima

b) Jika $b_{I}(I=1,2,3,4) \neq 0: \mathrm{H}_{\mathrm{o}}$ ditolak

\section{Uji statistik parsial}

Uji wald bertujuan guna memperhatikan pengaruh variabel independen terhadap variabel dependen secara individual, anggapan bahwa variabel lainnya konstan. Landasan uji wald dipakai guna memahami apakah setiap variabel bebas memiliki pengaruh terhadap variabel terikat. Uji dikerjakan dengan menggunakan tingkat signifikan $\leq 0,05$.

Dalam pengukuran pengaruh variabel bebas terhadap variabel terikat dilakukan satu per satu secara parsial menggunakan statistik uji wald dengan langkah-langkah berikut ini:

1. Menetapkan Hipotesis $\mathrm{Nol}\left(\mathrm{H}_{\mathrm{o}}\right)$ dan Hipotesis Alternatif $\left(\mathrm{H}_{\mathrm{A}}\right)$ sebagai berikut:

\section{Hipotesis Pertama $\left(\mathbf{H}_{1}\right)$}

a) $\mathrm{H}_{\mathrm{ol}}: \mathrm{b}_{1}=0:$ kondisi keuangan perusahaan tidak memengaruhi penerimaan going concern audit opinion.

b) $\mathrm{H}_{\alpha 1}: \mathrm{b}_{1} \neq 0:$ kondisi keuangan perusahaan memengaruhi penerimaan opini audit going concern opinion.

\section{Hipotesis Kedua $\left(\mathbf{H}_{2}\right)$}

a) $\mathrm{H}_{02}: \mathrm{b}_{2}=0:$ ukuran perusahaan tidak memengaruhi penerimaan going concern audit opinion. 
b) $\mathrm{H}_{02}: \mathrm{b}_{2} \neq 0:$ ukuran perusahaan memengaruhi penerimaan going concern audit opinion.

\section{Hipotesis Ketiga $\left(\mathbf{H}_{3}\right)$}

a) $\mathrm{H}_{03}: \mathrm{b}_{3}=0:$ Pertumbuhan perusahaan tidak memengaruhi penerimaan going concern audit opinion.

b) $\mathrm{H}_{\alpha_{3}}: \mathrm{b}_{3} \neq 0:$ Pertumbuhan perusahaan memengaruhi penerimaan going concern audit opinion.

\section{Hipotesis Keempat $\left(\mathbf{H}_{4}\right)$}
a) $\mathrm{H}_{04}: \mathrm{b}_{4}=0:$ Reputasi
KAP tidak berpengaruh terhadap penerimaan going concern audit opinion.
b) $\mathrm{H}_{a^{4}}: \mathrm{b}_{4} \neq 0:$ Reputasi KAP memengaruhi penerimaan going concern audit opinion.

2. Menetapkan ciri pengakuan dan pengingkaran hipotesis sebagai berikut:
a. Jika $b_{I}(I=1,2,3,4)=0: H_{0}$ diterima
b. Jika $b_{I}(I=1,2,3,4) \neq 0: H_{o}$ ditolak

Pengutipan keputusan kepada hipotesis juga dapat dikerjakan melalui perhitungan probabilitasnya ( $p$-value). Jika melihat $p$-value < nilai alfa $(\alpha)$ berarti tingkat keyakinan $(1-\alpha)$ bisa mengingkari hipotesis

\section{Hasil Dan Pembahasan}

\section{Statistik Deskriptif}

Statistik deskriptif menampilkan deskripsi perihal spesifik variabel yang di observasi. Perolehan analisis statistik deskriptif pada penelitian bisa diamati dalam Tabel 4.1.

\section{Tabel 4.1}

Descriptive Statistics

\begin{tabular}{|l|l|r|r|r|r|}
\hline & N & \multicolumn{1}{|c|}{ Min } & Max & \multicolumn{1}{c|}{ Mean } & \multicolumn{1}{c|}{$\begin{array}{c}\text { Std. } \\
\text { Deviation }\end{array}$} \\
\hline Opini Audit Going concern & 99 & .00 & 1.00 & .0404 & .19791 \\
Kondisi Keuangan Perusahaan & 99 & -12.29 & 28.16 & 2.4398 & 4.83500 \\
Ukuran Perusahaan & 99 & 25.64590 & 32.15567 & 29.1812537 & 1.51277403 \\
Pertumbuhan Perusahaan & 99 & .561 & 2.408 & 1.05705 & .238810 \\
Reputasi KAP & 99 & .00 & 1.00 & .5051 & .50252 \\
Valid N (listwise) & 99 & & & & \\
\hline
\end{tabular}
Sumber: Output SPSS (2018).

Tabel 4.1 menampilkan nilai terendah, tertinggi, rata-rata, dan standar deviasi dari setiap variabel dengan total observasi sebanyak 99 perusahaan. Opini audit going concern adalah variabel dependen yang dikategorikan menjadi dua, yaitu 0 bagi perusahaan yang tidak mendapatkan going concern audit opinion, dan 1 bagi perusahaan yang mendapatkan going concern audit opinion. Sementara variabel bebas yaitu kondisi keuangan perusahaan, ukuran perusahaan, pertumbuhan perusahaan, dan reputasi KAP.

Nilai terendah dari opini going concern audit opinion adalah 0 yang artinya perusahaan tidak memperoleh going concern audit opinion dan nilai tertingginya adalah 1 yang artinya perusahaan memperoleh going concern opinion. Nilai rata-rata going concern opinion sebesar 0.0404 atau 4,04\% yang didapatkan oleh perusahaan pertambangan yang terdaftar di BEI pada tahun 2015-2017. Sedangkan nilai standar deviasi sebesar 0,19791. Nilai standar deviasi going concern opinion lebih tinggi dari nilai rata-ratanya, hal ini mengindikasikan hasil yang kurang baik karena mencerminkan penyimpangan dari data variabel tersebut.

Variabel independen pertama yaitu kondisi keuangan perusahaan yang diukur menggunakan model altman modifikasi. Nilai terendah dari keseluruhan observasi kondisi keuangan perusahaan sebesar -12,291 yang didapatkan oleh PT Bumi Resources Tbk tahun 2017. Sementara nilai teratas sebesar 28,159 yang dialami oleh Central Omega Resources Tbk periode 2015. Nilai rata-rata dari kondisi keuangan perusahaan sebesar 2,43975 yang berarti nilai rata-rata dari perusahaan sampel sebesar $243,975 \%$. Sementara nilai standar deviasi dari kondisi keuangan perusahaan sebesar 4,835002.

Variabel independen kedua yaitu ukuran perusahaan yang diukur dari logaritma natural dari total aset perusahaan. Nilai tertinggi dari ukuran perusahaan yaitu 32,15567 yang didapatkan oleh Adaro Energy Tbk pada tahun 2017 dan nilai terbawah sebesar 25,64590 yang didapatkan oleh Perdana Karya Perkasa Tbk pada tahun 2017. Nilai rata-rata dari keseluruhan observasi pada variabel ukuran perusahaan sebesar 29,1812573 dan nilai standar deviasi sebesar 1,51277403.

Variabel independen ketiga adalah pertumbuhan perusahaan. Pertumbuhan perusahaan diukur dengan membandingkan total aset akhir tahun perusahaan dengan total aset awal tahun perusahaan. Nilai terendah dari keseluruhan observasi untuk variabel pertumbuhan perusahaan sebesar 0,561 yang dimiliki oleh Perdana Karya Perkasa Tbk periode 2015. Sedangkan untuk nilai tertinggi dimiliki oleh Surya Esa Perkasa Tbk pada periode 2016 dengan nilai sebesar 2,408. Nilai rata-rata pertumbuhan 
perusahaan sebanyak 1,05705 dan nilai standar deviasinya sebanyak 0,238810 .

Variabel independen terakhir yaitu reputasi KAP. Nilai terendah dari jumlah observasi untuk variabel reputasi KAP yaitu 0 yang artinya KAP tidak terafiliasi dalam bigfour, sementara nilai tertingginya adalah 1 untuk KAP yang terafiliasi di dalam bigfour. Nilai rata-rata reputasi KAP sebanyak 0,5051 dan standar deviasi sebanyak 0,50252 .

\section{Menilai Model Fit}

Serasi dengan apa yang telah ditampilkan pada bab sebelumnya, memperhitungkan model fit merupakan analisis awal yang dikerjakan. Dalam menghitung model fit hipotesis yang dipakai, yaitu:

$\mathrm{H}_{0}$ : Model yang dihipotesiskan cocok dengan data

Ha: Model yang dihipotesiskan tidak cocok dengan data

Uji dikerjakan dengan membandingkan antara nilai -2 log likehood (-2LL) di block number $=0$ dengan nilai -2 log likehood di block number $=1$. Penurunan nilai -2LL awal dengan -2LL akhir mengindikasikan model yang dihipotesiskan sesuai dengan data (Ghozali, 2009:79). Perbandingan nilai 2LL awal pada block 0 dengan nilai -2LL akhir pada block 1 dapat dilihat pada Tabel 4.2.

Tabel 4.2

Perbandingan Nilai -2LL Awal dengan Nilai -2LL Akhir

\begin{tabular}{|c|c|}
\hline -2LL Awal (number block $=0)$ & 33,507 \\
\hline -2LL Akhir (number block $=1$ ) & 12,886 \\
\hline Sumber: Data diolah (2018).
\end{tabular}

Dari Tabel 4.2 dapat dilihat nilai $-2 \quad \log$ likehood awal mengalami penurunan nilai setelah dilakukan perbandingan dengan nilai -2 log likehood akhir. Hal ini berarti ketika variabel independen (kondisi keuangan perusahaan, ukuran perusahaan, pertumbuhan perusahaan, dan reputasi KAP) dimasukkan ke dalam model, nilai akhir dari -2 log likehood mengalami penurunan sebesar 20,621, dari nilai awalnya, sehingga nilai akhir dari -2 log likehood sebesar 12,261,. Pengurangan -2 log likehood menggambarkan bahwa model regresi yang dihipotesiskan memiliki kesesuaian data atau bahasa lainnya $\mathrm{H}_{0}$ diterima. Hasil perhitungan.

\section{Uji Kelayakan Model Regresi}

Uji layak model regresi adalah analisis dikerjakan selanjutnya. Uji kelayakan model regresi pada penelitian ini memakai Hosmer and Lemeshow Goodness of Fit Test yang ditampilkan dengan nilai Chi-Square. $\mathrm{H}_{0}$ ditolak apabila nilai signifikansi chisquare $\leq 0,05$. Hal ini menunjukkan bahwa ditemukan kelainan antara model dengan nilai observasi yang mengakibatkan nilai Goodness of Fit Test belum mampu memprediksi nilai pengamatannya. Sebaliknya apabila nilai signifikansi chi-square melebihi 0,05 menunjukkan bahwa $\mathrm{H}_{0}$ diterima dan dapat memperkirakan nilai observasinya karena memiliki kesesuaian dengan data yang diobservasi. Berikut ini Tabel 4.3 yang berupa hasil pengujian kelayakan model regresi.

Tabel 4.3

Hosmer and Lemeshow Test

\begin{tabular}{lr|r|r} 
Step & Chi-square & Df & Sig. \\
\hline 1 & .582 & 8 & 1.000 \\
\hline \multicolumn{3}{|l}{ Sumber: Output SPSS (2018). }
\end{tabular}

Berdasarkan Tabel 4.3 bisa diketahui bahwa nilai Hosmer and Lemeshow Test sebesar 0 dengan probabilitas signifikansi 1.000 . Oleh karena nilai probabilitas signifikan $>0,05$, maka $\mathrm{H}_{0}$ tidak dapat ditolak. Keadaan ini menunjukkan model regresi memadai guna dipakai pada analisis selanjutnya dikarenakan tidak terdapat kelainan nyata antara klarifikasi yang diperkirakan dengan klarifikasi yang dipantau. Artinya model regresi sanggup memprediksi nilai observasinya.

\section{Koefisien Determinasi}

Koefisien determinasi dapat memberikan informasi mengenai besarnya kemampuan variabilitas variabel-variabel bebas menjelaskan variabilitas variabel bebas. Pada pengujian regresi logistik, koefisien determinasi bisa dilihat pada Nagelkerke $R$ Square. Nilai koefisien determinasi terletak di antara angka 0 dan 1 . Hasil pengujian koefisien determinasi bisa dilihat pada Tabel 4.4.

Tabel 4.4

Model Summary

\begin{tabular}{cc|c|c} 
& -2 Log & Cox \& Snell & Nagelkerke R \\
Step & likelihood & R Square & Square \\
\hline
\end{tabular}

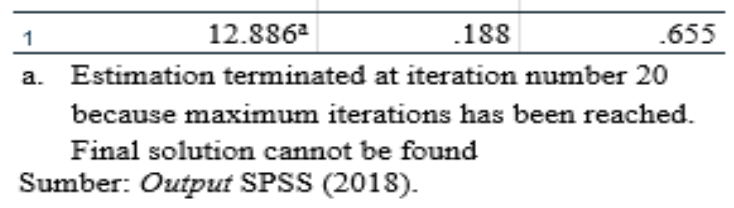


Tabel 4.4 menampilkan nilai Cox \& Snell $R$ Square sebesar 0,188 dan Nagelkerke's $R$ Square sebanyak 0,655 yang berarti variabilitas variabel terikat (opini audit going concern) mampu diungkapkan oleh variabilitas variabel bebas (kondisi keuangan perusahaan, ukuran perusahaan, pertumbuhan perusahaan, dan reputasi KAP) sebanyak $65,5 \%$, sisanya sebanyak $34,5 \%$ variabilitas pada variabel terikat dijelaskan oleh berbagai faktor diluar variabel bebas yang digunakan pada penelitian.

\section{Tabel Klasifikasi}

Tabel klasifikasi memperlihatkan estimasi dari model guna memperhitungkan kemungkinan perusahaan mendapatkan going concern audit opinion yang ditampilkan oleh classification table pada Tabel 4.5. Pada kolom adalah dua nilai estimasi dari variabel terikat, pada baris memperlihatkan nilai pengamatan sebenarnya dari variabel terikat.

Tabel 4.5

\begin{tabular}{|c|c|c|c|c|c|}
\hline \multicolumn{6}{|c|}{ Classification Table ${ }^{a}$} \\
\hline & \multicolumn{2}{|c|}{ Observed } & \multicolumn{3}{|c|}{ Predicted } \\
\hline & & & \multicolumn{2}{|c|}{ opini } & \multirow[b]{2}{*}{ Percentage Correct } \\
\hline & & & .00 & 1,00 & \\
\hline \multirow[t]{3}{*}{ Step 1} & opini & Non going concern & 24 & 1 & 98,0 \\
\hline & & going concern & 2 & 2 & 50,0 \\
\hline & \multicolumn{2}{|c|}{ Overall Percentage } & & & 97,0 \\
\hline
\end{tabular}

g. The cut value is, 500

Sumber: Output SPSS (2018)

Berdasarkan Tabel 4.5 matriks klasifikasi menampilkan kemampuan perkiraan dari model regresi guna mengestimasikan peluang perusahaan mendapatkan penerimaan going concern audit opinion. Kemampuan dari model regresi guna mengestimasikan kemampuan perusahaan memperoleh penerimaan going concern audit opinion adalah 50\%. Keadaan ini membuktikan bahwa dengan memakai model regresi yang dilakukan diperoleh sejumlah 2 perusahaan yang diperkirakan akan mendapatkan going concern audit opinion dari total 4 perusahaan yang seharusnya mendapatkan going concern audit opinion. Sedangkan kemampuan dari model regresi untuk peluang penerimaan opini nongoing concern adalah sebanyak $98 \%$ yang artinya dengan model regresi yang digunakan sebesar 94 sampel diestimasi menerima nongoing concern audit opinion dari total 95 perusahaan yang mendapatkan nongoing concern audit opinion. Secara menyeluruh kemampuan perkiraan dari model regresi pada penelitian berikut ini sebesar $97 \%$.

\section{Hasil Pengujian Hipotesis \\ Uji Statistik Simultan}

Omnibus Test of Model Coefficient digunakan untuk mengetahui pengaruh Kondisi keuangan perusahaan, ukuran perusahaan, pertumbuhan perusahaan dan reputasi KAP secara simultan terhadap penerimaan opini audit going concern. Perolehan pengujian hipotesis dapat dilihat pada Tabel 4.6.

Tabel 4.6

Omnibus Tests of Model Coefficients

\begin{tabular}{llr|r|r} 
& & Chi-square & df & \multicolumn{1}{c}{ Sig. } \\
\hline Step 1 & Step & 20.620 & 4 & .000 \\
\cline { 2 - 5 } & Block & 20.620 & 4 & .000 \\
\cline { 2 - 5 } & Model & 20.620 & 4 & .000 \\
\hline
\end{tabular}

Sumber: Output SPSS (2018).

$\mathrm{H}_{1}$ : Kondisi keuangan perusahaan, ukuran perusahaan, pertumbuhan perusahaan dan reputasi KAP secara bersama-sama/simultan terhadap penerimaan Opini Audit Going Concern pada perusahaan pertambangan yang terdaftar di Bursa Efek Indonesia tahun 2015-2017.

Berdasarkan Tabel 4.6, hasil penelitian menunjukkan bahwa kondisi keuangan perusahaan, ukuran perusahaan, pertumbuhan perusahaan dan reputasi KAP secara simultan memengaruhi penerimaan going concern audit opinion ditunjukkan oleh nilai signifikansi sejumlah 0,000 dan kurang dari nilai taraf signifikan $0,05(5 \%)$.

\section{Uji Statistik Parsial}

Uji wald bertujuan guna mengamati pengaruh antar variabel bebas terhadap variabel terikat secara individual, dengan anggapan variabel lain konstan. Uji wald pada dasarnya dilakukan untuk memahami apakah setiap variabel bebas memengaruhi variabel terikat. Perolehan uji wald dapat dilihat pada tabel 4.7 


\begin{tabular}{|c|c|c|c|c|c|c|c|}
\hline & & Tabel & & & & & \\
\hline & & & & & & & \\
\hline & & $\mathrm{B}$ & S.E. & Wald & Df & Sig. & $\operatorname{Exp}(B)$ \\
\hline Ste & Kondisi_keuangan_perusahaan & .075 & .235 & .101 & 1 & .751 & 1.078 \\
\hline $1^{\mathrm{a}}$ & Ukuran perusahaan & 1.713 & .831 & 4.246 & 1 & .039 & 5.546 \\
\hline & Pertumbuhan perusahaan & -20.215 & 8.935 & 5.119 & 1 & .024 & .000 \\
\hline & Reputasi KAP & 19.927 & 4320,041 & .000 & 1 & .996 & $\begin{array}{c}4508039 \\
91,6\end{array}$ \\
\hline & Constant & -53.899 & 4320.086 & .000 & 1 & .990 & .000 \\
\hline
\end{tabular}

a. Variable(s) entered on step 1: Kondisi_keuangan_Perusahaan. Ukuran_Perusahaan. Pertumbuhan perusahgan, Reputasi KAP.

$\mathrm{H}_{2}$ : kondisi keuangan perusahaan memengaruhi penerimaan opini audit going concern pada perusahaan pertambangan.

Berdasarkan Tabel 4.7, Perolehan penelitian terhadap kondisi keuangan perusahan memperlihatkan bahwa koefisien regresi positif sejumlah 0,075 dan nilai Wald dengan signifikansi sejumlah 0,751 (>0,05) maka $\mathrm{H}_{2}$ diingkari. Oleh karena itu, perolehan perincian memperlihatkan bahwa secara individual variabel kondisi keuangan tidak memengaruhi penerimaan going concern audit opinion. Perolehan dari penelitian ini tidak mendukung hipotesis 2 .

$\mathrm{H}_{3}$ : ukuran perusahaan memengaruhi penerimaan going concern audit opinion pada perusahaan pertambangan.

Berlandaskan Tabel 4.7, perolehan penelitian terhadap ukuran perusahaan memperlihatkan koefisien regresi positif sejumlah 1.713 dan nilai Wald dengan signifikansi sebesar .039 $(<0,05)$ maka $\mathrm{H}_{3}$ diterima. Berarti hasil perhitungan statistik memperlihatkan bahwa secara individual faktor ukuran perusahaan memengaruhi penerimaan going concern audit opinion. Hipotesis 3 diduking hasil penelitian ini.

$\mathrm{H}_{4}$ : pertumbuhan perusahaan memengaruhi penerimaan going concern audit opinion pada perusahaan pertambangan.

Berlandaskan Tabel 4.7, perolehan penelitian terhadap ukuran perusahaan memperlihatkan koefisien regresi negatif sejumlah $-20,215$ dan nilai Wald dengan taraf signifikansi sejumlah $0,024 \quad(<0,05)$ maka $\mathrm{H}_{4}$ diterima. Maka dari itu, perolehan perhitungan statistik menampilkan secara individual pertumbuhan perusahaan memengaruhi penerimaan going concern audit opinion. Hipotesis 4 diduking hasil penelitian ini.

$\mathrm{H}_{5}$ : Reputasi KAP memengaruhi penerimaan opini audit going concern pada perusahaan pertambangan yang terdaftar di BEI.
Berdasarkan Tabel 4.7, hasil penelitian terhadap reputasi KAP menunjukkan bahwa koefisien regresi positif sejumlah 19,927 dan nilai Wald dengan taraf signifikansi sejumlah 0,996 (>0,05) berarti $\mathrm{H}_{5}$ dipungkiri. Oleh sebab itu, perolehan perhitungan statistik menampilkan bahwa secara individual reputasi KAP tidak memengaruhi penerimaan going concern audit opinion. Hasil dari penelitian ini tidak mendukung hipotesis 5 .

Dari percobaan dengan regresi logistik, didapatkan persamaan yaitu:

$\mathrm{LN} \frac{G C}{1-G C}=-53,899+0,75 \mathrm{X} 1+1,713 \mathrm{X} 2-20,215 \mathrm{X} 3+19,927 \mathrm{X} 4+\mathrm{e}$

Penjelasan dari persamaan di atas adalah:

a) Nilai konstanta sebanyak $-53,899$ memperlihatkan bahwa jika variabel kondisi keuangan perusahaan, ukuran perusahaan, pertumbuhan perusahaan dan reputasi KAP dianggap konstan, maka nilai $-53,899$ menunjukkan besarnya prediksi mendapatkan penerimaan opini audit going concern bernilai negatif. Berarti perusahaan bisa keluar dari keadaan mendapatkan penerimaan going concern audit opinion dan atau dapat dikatakan memperoleh penerimaan non-going concern audit opinion .

b) Koefisien regresi kondisi keuangan perusahaan yang dinotasikan melalui $\mathrm{X}_{1}$ adalah sebanyak 0,75 . Berarti setiap $100 \%$ peningkatan pada variabel kondisi keuangan, penerimaan opini audit going concern yang didapatkan oleh perusahaan akan bertambah sebanyak $75 \%$ dengan anggapan variabel bebas lain dalam rumus dinilai stabil.

c) Koefisien regresi ukuran perusahaan yang dinotasikan melalui $\mathrm{X}_{2}$ adalah sebanyak 1,713. Berarti setiap $100 \%$ peningkatan pada variabel ukuran perusahaan maka penerimaan opini audit going concern yang didapatkan oleh perusahaan akan bertambah sebanyak $171,3 \%$ dengan anggapan variabel bebas lain pada model dinilai stabil.

d) Koefisien regresi pertumbuhan perusahaan yang disimbolkan melalui $\mathrm{X}_{3}$ adalah sebanyak -20,215. Berarti setiap $100 \%$ peningkatan pada variabel ukuran perusahaan maka maka going concern audit opinion yang didapatkan oleh perusahaan akan menurun sebesar sebesar 2021,5\% dengan 
anggapan variabel bebas lain pada model dinilai konstan.

e) Koefisien regresi reputasi KAP yang dinotasikan melalui $\mathrm{X}_{4}$ sebesar 19,927. Artinya, setiap kenaikan $100 \%$ dalam variabel reputasi KAP maka maka opini audit going concern yang didapatkan oleh perusahaan akan mengalami peningkatan sebanyak 1992,7\% dengan anggapan variabel bebas lain pada model dinilai konstan.

f) Epsilon (error term) atau $\varepsilon$ berarti ada faktorfaktor (berbagai variabel) lain yang dapat memengaruhi going concern audit opinion selain dari faktor kondisi keuangan perusahaan, ukuran perusahaan, pertumbuhan perusahaaan dan reputasi KAP.

\section{Kesimpulan, Keterbatasan Dan Saran Kesimpulan}

Berlandaskan pengkajian perolehan penelitian yang sudah dijelaskan, maka bisa disimpulkan:

a) kondisi keuangan perusahaan, ukuran perusahaan, ,pertumbuhan perusahaan, dan reputasi KAP secara bersama-sama memengaruhi penerimaan opini audit going concern pada perusahaan pertambangan.

b) Kondisi keuangan perusahaan tidak memengaruhi penerimaan opini audit going concern pada perusahaan pertambangan.

c) Ukuran perusahaan memengaruhi penerimaan opini audit going concern pada perusahaan pertambangan.

d) Pertumbuhan perusahaan memengaruhi penerimaan opini audit going concern pada perusahaan pertambangan.

e) Reputasi KAP tidak memengaruhi penerimaan opini audit going concern pada perusahaan pertambangan.

\section{Keterbatasan Penelitian}

Penelitian ini ada sebagian kekurangan yang bisa diamati anjuran bagi penelitian selanjutnya diharapkan dapat mencapai hasil yang makin bagus di masa mendatang, Di antaranya:

1. Penelitian hanya dikerjakan di perusahaan pertambangan yang tercatat di BEI dengan berbagai kriteria terpilih yang sudah ditentukan sebelumnya, sehingga belum bisa disama ratakan bagi semua perusahaan yang tercatat di BEI
Bentang waktu yang dipakai pada penelitian ini berjumlah tiga tahun, hal ini mengakibatkan sedikitnyabesaran perusahaan yang menjadi sampel.

2. Data penelitian yang digunakan tidak seimbang, kondisi beberapa data yang besarannya relatif tidak biasa karena datanya tidak bagus.

\section{Saran}

Berlandaskan perolehan penjabaran pembahasan dan sebagian kesimpulan dan keterbatasan dalam penelitian, Saran yang bisa dibagikan supaya tercapai perolehan yang makin bagus:

\section{Saran Akademis}

1. Sehubungan dengan penelitian ini pada sektor pertambangan saja, untuk penelitian selanjutnya diminta dapat memperluas subjek penelitian supaya populasi yang dicapai lebih representatif dan perolehan penelitiannya dapat disama ratakan bagi seluruh jenis perusahaan.

2. Penelitian selanjutnya diharapkan memakai bentang waktu lebih luas supaya dapat mempersembahkan perolehan yang lebih valid.

3. Diharapkan penelitian selanjutnya agar dapat menggunakan pengukuran lain untuk variabel kondisi keuangan perusahaan selain model Altman modifikasi yang digunakan di penelitian ini.

\section{Saran Praktisi}

1. Untuk investor yang hendak menginvestasikan saham pada suatu perusahaan, lebih baik mengamati terlebih dahulu variabel kondisi keuangan perusahaaan, ukuran perusahaan, pertumbuhan perusahaan, dan reputasi KAP secara bersamaan, serta mempertimbangkan faktor pertumbuhan perusahaan dan ukuran perusahaan secara individual, hal ini mengingat hasil penelitian yang berpengaruh terhadap faktor tersebut agar tidak salah dalam memilih keputusan untuk investasi.

2. Untuk perusahaan untuk tetap mempertimbangkan rencana yang akan diambil agar perusahaan terbebas dari penerimaan going concern audit opinion 


\section{Daftar Pustaka}

Alfaizatul, U. 2014. Opini Audit Going Concern: Analisis Berdasarkan Faktor Keuangan Dan Non Keuangan. Accounting Analysis Journal, 3(1), 361-369.

Arisandy, Z., M. Mustafa., Dan Haeiral. 2015. Pengaruh Ukuran Perusahaan, Pertumbuhan Perusahaan, Dan Opini Audit Tahun Sebelumnya Terhadap Opini Audit Going Concern.Jurnal Akuntansi Fakultas Ekonomi Universitas Hasanudin. Makasar.

Arsianto, M. R., \& Rahardjo, S. N. 2014. FaktorFaktor Yang Mempengaruhi Penamerimaan Opini Audit Going Concern. Simposium Nasional Akuntansi X, 11(3),1-26. Https://Doi.Org/10.13140/Rg.2.2.30630.3232 4

Bank Indonesia, 2018, Laporan Perekonomian Indonesia 2017, Publikasi Tahunan Bank Indonesia, BI Jakarta.

Boynton, C, William., Raymond N. Johnson And Walter G Kell. 2001. Modern Auditing, Sixth Edition, John Wiley \& Sons Inc.

Brigham, Eugene F. dan Joel F. Houston. 2011. Dasar-dasar Manajemen Keuangan. Edisi 11 Buku 2. Jakarta : Salemba Empat.

Bursa Efek Indonesia. 2018 Laporan Keuangan dan Tahunan. www.idx.co.id. Diakses pada jum'at, 24 juni 2018 jam 9.20

Dewayanto, T. 2011. Penerimaan Opini Audit Going Concern Terdaftar Di Bursa Efek Indonesia. Fokus Ekonomi, 6(1), 81-104.

Dhartia, S. P., 2012. Analisis Determinan Praktik Income Smoothing. Jurnal Institut Manajemen Telkom.

Djufri. 2011. Memahami Opini Audit Going Concern Dalam Rangka Investasi Di Pasar Modal. Buku Aktiva, Vol. 4, No. 7, Oktober, Hlm. 83-97.

Fanny, M. dan Saputra, S. 2005. Opini Audit Going Concern: Kajian Berdasarkan Model Prediksi Kebangkrutan, Pertumbuhan Perusahaan, dan Reputasi Kantor Akuntan Publik (Studi Pada Emiten Bursa Efek Jakarta). Prosiding Simposium Nasional Akuntansi VIII: Solo

Gallizo, J. L., dan Saladrigues, R. 2015. An Analysis Of Determinants Of Going Concern Audit Opinion : Evidence From Spain Stock

\section{Exchange. Universitat De Lleida (Spain)}

Ghozali, I. 2009. Aplikasi Analisis Multivariat Dengan Program SPSS. Semarang: UNDIP.

Ghozali, I. 2011. Aplikasi Analisis Multivariat Dengan Program SPSS. Semarang: Badan Penerbit Universitas Diponegoro.

Ghozali, I. 2012. Aplikasi Analisis Multivariat Dengan Program SPSS. Yogyakarta: Badan Penerbit Universitas Diponegoro.

Ghozali, I. 2013. Aplikasi Analisis Multivariat Dengan Program SPSS. Edisi ke tujuh. Semarang: Badan Penerbit Universitas Diponegoro.

Haron, H., Hartadi, B., Ansari, M., \& Ismail, I., 2009. Factors Influencing Auditors' Going Concern Opinion. Asian Academy of Management Journal, 14(1), 1-19.

Institut Akuntan Publik Indonesia. 2011. Standar Profesional Akuntan Publik Seksi 341 Pertimbangan Auditor Akan Kemampuan Entitas Dalarn Mempertahankan Keberlangsungan Hidupnya, Jakarta: Salemba Empat

Institut Akuntan Publik Indonesia, 2014. "Standar Profesional Akuntan Publik", Standar Audit ("SA") 700 tentang Perumusan suatu opini dan pelaporan atas laporan keuangan,Jakarta, penerbit Salemba.

-----------, "Standar Profesional Akuntan Publik", Standar Audit ("SA") 705 tentang modifikasi terhadap opini dalam pelaporan auditor independen, Jakarta penerbit Salemba

Jayanti, Q. 2015. Analisis Tingkat Akurasi ModelModel Prediksi Kebangkrutan Untuk Memprediksi Voluntary Auditor Switching ( Studi Pada Perusahaan Manufaktur Yang Terdaftar Di Bei ). Modus, 27(2), 87-108.

Junaidi dan Hartono, J. 2010. Faktor Non Keuangan pada Opini Going Concern. Simposium Nasional Akuntansi XIII Purwokerto: 1-23.

Junaidi dan Nurdiono. 2016. Kualitas Audit. (B. Hartadi, Ed.). Yogyakarta. Retrieved From Https://Books.Google.Co.Id/Books?Id=5xo6d gaaqbaj\&Printsec $=$ Frontcover $\& H \mathrm{H}=\mathrm{Id} \&$ Sourc e=Gbs_Ge_Summary_R\&Cad=0\#V=Onepage $\& Q \& F=$ False

Kristiana, I. 2012. Pertumbuhan Perusahaan Terhadap Opini Audit Going Concern Pada Perusahaan 
Manufaktur Yang Terdaftar Di Bursa Efek Indonesia ( Bei ). Jurnal Akuntansi, 1(1), 4751 .

Kusumayanti, N. P. E., \& Widhiyani, N. L. S., 2017. Pengaruh Opinion Shopping, Disclosure dan Reputasi Kap Pada Opini Audit Going Concern. E-Jurnal Akuntansi Universitas Udayana, 18(3), 2290-2317.

Lennox, C., 2002. "Going-Concern Opinions In Failing Companies: Auditor Dependence And Opinion Shopping".

Lestari, N. L. P. R. W. dan Widhiyani, N. L. S., 2014. Auditor Pada Kualifikasi Opini Keberlangsungan Fakultas Ekonomi Dan Bisnis Universitas Udayana ( Unud ), Bali , Indonesia Konflik Pihak Manajer ( Agent) Dengan Pihak Pemegang Saham ( Principal) Adalah. E-Jurnal Akuntansi Universitas Udayana, 6(3), 439-452.

Mckeown, J, Mutchler, J Dan Hopwood. W, 1991. Towards An Explanation of Auditor Failure To Modify The Audit Opinions Of Bankrupt Companies. Auditing: A Journal Practice \& Theory. Supplement. 1-13.

Nurfitriyani, A. 2017. Bei Persilakan Perusahaan Yang Telah Delisting Untuk Relisting.Wartaekonomi.

RetrievedFrom

Https://Www.Wartaekonomi.Co.Id/Read1588

81/Bei-Persilakan-Perusahaan-Yang-Telah-

Delisting-Untuk-Relisting.Html

Oktavia. 2010. Going Concern Dan Implikasinya Terhadap, 10, 305-328.

Peraturan Menteri Perdagangan Nomor 36/MDag/Per/9/2007 Tentang Penerbitan Surat Izin Usaha Perdagangan (SIUP)

Purba, M. 2009. Asumsi Going Concern: Suatu Tinjauan Terhadap Dampak Krisis Keuangan Atas Opini Audit Dan Laporan Keuangan. Yogyakarta: Graha Ilmu.

Rudyawan, A. P., \& Badera, I. D. N., (2002). Opini Audit Going Concern: Kajian Berdasarkan Model Prediksi Kebangkrutan, Pertumbuhan Perusahaan, Leverage, Dan Reputasi Auditor. Jurnal Bisnis Dan Akuntansi, 1-17.

Sahamok. 2018. Daftar emiten/perusahaan publik/ perusahaan terbuka / perusahaan tbk yang di delisting dari Bursa Efek Indonesia. Retrieved

\section{From}

https://www.sahamok.com/emiten/sahamdelisting/

Saputra, R. E., \& Praptoyo, S. 2017. Analisis Faktor Yang Mempengaruhi Opini Audit Terkait Going Concern. Jurnal Ilmu Dan Riset Akuntansi, 6(2), 683-702.

Sekaran, U., \& Bougie R.2013. Research Mehods For Business: A Skill Building Approach. $6^{\text {th }}$ Edition New York: John Wiley \& Sons, Ltd.

Setyarno, E. B., Januarti, I., \& Faisal. (2006). Pengaruh Kualitas Audit, Kondisi Keuangan Perusahaan, Opini Audit Tahun Sebelumnya, Pertumbuhan Perusahaan Terhadap Opini Audit Going Concern. Simposium Nasional Akuntansi Ix, 1-25. 